\title{
菌学面からみたマイコトキシンの動向一一食品由来 糸状菌のマイコトキシン産生性
}

\author{
一 戸 正 勝*1
}

M. ICHINOE*1 : Bioproduction of mycotoxins by fungi isolated from foodstuffs

マイコトキシンが，食品あるいは飼料を污染するにいたるまでには菌学的にみたいくつかの条件 がととのわなければならない，すなわち，(1)食品，飼料などの基質に多量のカビが存在すること， (2)検出菌類の中に占めるマイコトキシン産生菌種の比率が高いとと，(3)カビ発生基質がマイコトキ シン蓄積に適したあのであるとと，(4)温度，水分など基質とカビ類のおかれた環境条件…....などが 重なった結果として，マイコトキシン自然污染があたらされる.

一方, マイコトキシンが化学的に検出可能な量に至らない微量に污染された食品, 飼料を摄取し つづけるうちに，特異的な急性症状のみられないまま，慢性的な障害を受ける可能性む考えられよ う. マイコトキシン自然污染の条件として, 食品, 飼料におけるマイコトキシン産生菌の分布状況 を把握しておくことは，食品衛生上からみて意義のあることである.

\section{1. アフラトキシン (AF) とステリグマトシスチン $(\mathrm{ST})$}

強力な発がん性を有し，かつ自然污染例の多い AF は最重要視されるあのである．ついで ST は 急性毒性は弱いが，発がん性があり，ST を主に産生する A. versicolor が眝蔵穀類を中心に広く 分布するとてろから重要なマイコトキシンといえる.

国内で流通している主な食品, 食品原料, 飼料などでの AF, ST 産生菌の検出頻度につき, 著者 らの成績を中心にまとめたのが Table 1 である.

まず，A.favus の AF 産生をみると，国内産精白米では A. flavus の分離頻度が低く, AF 産 生菌が得られなかったが，宮木ら1による玄米，精白米の結果であ同様であった．これに対し，麦 類，その加工品からは A. Alavus が優先菌として分離されることが多く，AF 産生菌は供試菌の

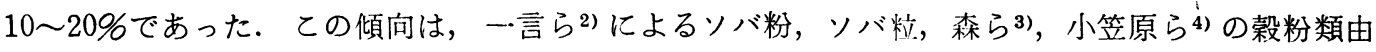
来菌においてあ認められている.

とてろが，輸入トウモロコシ，落花生では AF 産生菌の比率はより高くなり，鶴田ら5) は飼料用 トゥモロコシに高い $\mathrm{AF}$ 産生能 $(764 \mathrm{ppm})$ を持つ菌株を見出している.トウモロコシ，マイロ， 落花生粕などを原料とする配合飼料においてす AF 産生菌の 検出頻度は高い. 国産落花生では A. Alavus の分離頻度が低いにもかかわらず，AF 産生菌が得られている.

A. versicolor の ST 産生は Table 1 のように産生菌の占める割合が高く, 菌分布と合せて考慮 すると，むっと重要視すべきあのといえる.

表以外にあ穀粉類由来の A. versicolor, A. nidulans に ST 産生菌が高頻度に得られており4), 各種の食品に ST 産生性の $A$. versicolor がきわめて普遍的に存在するてとを示している. ST 自然

*1 国立衛生試験所真菌室（東京都世田谷区上用㖞1-18-1)

Laboratory of mycology, National Institute of Hygienic Sciences (Kamiyoga 1-chome, Setagaya-ku, Tokyo) 
Table 1. Aflatoxin and sterigmatocystin production by A. flavus and $A$. versicolor isolated from foods and feeds

\begin{tabular}{|c|c|c|c|}
\hline Sample & Fungi & $\begin{array}{l}\text { No. of strains } \\
\text { examined }\end{array}$ & $\begin{array}{l}\text { Mycotoxins } \\
\text { producer }\end{array}$ \\
\hline Polished rice & A. flavus & 6 & 0 \\
\hline Wheat flour & A. flavus & 12 & $1(8.3 \%)^{* 3}$ \\
\hline \multirow[t]{2}{*}{ Rice grain*1 } & A. flavus & 14 & 0 \\
\hline & A. versicolor & 58 & $18(31.0)$ \\
\hline \multirow[t]{2}{*}{ Wheat grain } & A. flavus & 32 & $6(18.8)$ \\
\hline & A. versicolor & 17 & $12(70.6)$ \\
\hline \multirow[t]{2}{*}{ Barley grain } & A. flavus & 26 & $3(11.5)$ \\
\hline & A. versicolor & 31 & $20(64.5)$ \\
\hline \multirow[t]{2}{*}{ Crumb } & A. flavus & 10 & $1(10.0)$ \\
\hline & A. versicolor & 9 & $6(66.7)$ \\
\hline Imported corn*2 & A. flavus & 57 & $32(56.1)$ \\
\hline Imported corn & A. flavus & 45 & $8(17.8)$ \\
\hline \multirow[t]{2}{*}{ Domestic peanut } & A. flavus & 6 & $2(33.3)$ \\
\hline & A. versicolor & 14 & $13(92.9)$ \\
\hline \multirow[t]{2}{*}{ Imported peanut } & A. flavus & 261 & $163(62.4)$ \\
\hline & A. parasiticus & 36 & $36(100)$ \\
\hline \multirow[t]{2}{*}{ Cattle feeds } & A. flavus & 12 & $2(16.7)$ \\
\hline & A. versicolor & 11 & $5(45.5)$ \\
\hline \multirow[t]{2}{*}{ Swine feeds } & A. flavus & 19 & $6(31.6)$ \\
\hline & A. versicolor & 9 & $6(66.7)$ \\
\hline Chicken feeds & A. flavus & 9 & $6(66.7)$ \\
\hline
\end{tabular}

污染例の報告はまだ少ないが, Schroeder ら ${ }^{6)}$ にる A. glaucus, A. flavus 菌群の ST 産生報告を みても, 今後, $\mathrm{AF}$ と同様に精力的な自然污染の追求がのぞまれるマイコトキシンである.

\section{2. オクラトキシン $(\mathbf{O C H})$ とペニシリン酸 $(\mathbf{P A})$}

わが国での $\mathrm{OCH}$ 産生菌は Natori ら7)の A. ochraceus 以来，米穀8)，麦類9)などから分離した A. ochraceus 菌群を対象に検討が行なわれてきたが，米由来株では 29 株中 2 株, 小麦由来株で 7 株 中 1 株，大麦由来株15株中 4 株が $\mathrm{OCH}$ 産生性を示し，供試菌に対する割合は低い。

A. ochraceus 菌群は $\mathrm{OCH}$ の他，PA を産生するととが知られているが，乙の菌群の $\mathrm{OCH}, \mathrm{PA}$ 両マイコトキシンの産生状況を Ciegler ${ }^{10)}$ の成績と著者らの成績を対比したのが Table 2 である.

表のように A. ochraceus 菌群の中で, かなり広範囲の菌種に $\mathrm{OCH}$ 産生が認められ, A. Aavus 菌群の中で, AF 産生菌が A. Aavus, A. parasiticus に限定される傾向とは異っていた.

PA は供試菌株の大部分に産生能があり，乙れは，A. versicolor の ST 産生と同様であった.

近年，P. viridicatum など数種のPenicillium 類に $\mathrm{OCH}$ 産生性が認められ，とくに $\mathrm{OCH}$ 自 然污染例からは，主として P. viridicatum が検出されるとする報告が多くなった. 代表的な報告 例を Table 3 に示す.

Scott ら ${ }^{11)}$ は $\mathrm{OCH}$ 自然污染の穀類より $\mathrm{OCH}$ 産生菌として P. viridicatum, P. palitans, Mintzlaff ら ${ }^{12)}$ はカビ付醱酵型ソーセージ由来の Penicillium 類に $\mathrm{OCH}$ 産生菌を見出している. 
Table 2. Ochratoxin and penicillic acid production by Aspergillus ochraceus group fungi

\begin{tabular}{lccc}
\hline & \multirow{2}{*}{$\begin{array}{c}\text { No. of } \\
\text { strains } \\
\text { examined }\end{array}$} & \multicolumn{2}{c}{$\begin{array}{c}\text { Mycotoxins } \\
\text { producer }\end{array}$} \\
\cline { 3 - 4 } & OCH-A & PA \\
\hline A. ochraceus*1 & 17 & 8 & 6 \\
A. melleus & 5 & 4 & 5 \\
A. sclerotiorum & 4 & 2 & 4 \\
A. alliaceus & 2 & 2 & 0 \\
A. sulphureus & 1 & 1 & 1 \\
A. ostianus & 1 & 1 & 1 \\
\hline A. ochraceus*2 & 6 & 2 & 5 \\
A. sclerotiorum & 7 & 2 & 6 \\
A. ostianus & 4 & 1 & 4 \\
A. petrakii & 2 & 0 & 1 \\
A. melleus & 1 & 0 & 1 \\
A. elegans & 1 & 0 & 1 \\
A. sulphureus & 1 & 0 & 1 \\
\hline . Dan & 1 & & \\
\hline
\end{tabular}

*1 Data from Ciegler (10),

*2 Data from Ichinoe et al. (9)
Table 3. Ochratoxin production by Penicillium spp. from foods

\begin{tabular}{lcc} 
Species & $\begin{array}{c}\text { No. of } \\
\text { strains } \\
\text { examined }\end{array}$ & $\begin{array}{c}\text { Ochratoxin } \\
\text { producer }\end{array}$ \\
\hline$P$. viridicatum*1 & 32 & 27 \\
$P$. palitans & 2 & 1 \\
$P$. cyclopium & 16 & 0 \\
\hline$P$. viridicatum*2 & 32 & 12 \\
$P$. variabile & 2 & 2 \\
$P$. commune & 5 & 1 \\
$P$. cyclopium & 3 & 1 \\
$P$. purpurescens & 1 & 1 \\
(Penicillium spp.) & $(422)$ & $(17)$ \\
\hline$P$. viridicatum & 28 & 17 \\
\hline
\end{tabular}

*1 Data from Scott et al. (11),

*2 Data from Mintzlaff et al. (12),

*3 Data from Sugimoto et al. (13)

わが国でも，最近，杉本ら ${ }^{13)}$ は $\mathrm{OCH}$ 自然污染長期保存米よりP. viridicatum を分離し，それら に OCH の他, チトリニンの産生を確認している.

PA は A. ochraceus 菌群の他，多くのPenicillium 類に産生性が知られているが，著者ら ${ }^{14)}$ は 輸入農作物由来 Penicillium 中, P.cyclopium, P. viridicatum, P. simplicissimum, P.puberulum, P. martensii などに液体培養で $39.2 \sim 400 \mu \mathrm{g} / \mathrm{ml}$ の PA 産生菌を得ている. Mintzlaff ら12) 多数 のPenicillium に PA 産生菌を報告している.しかしながら，PA の自然污染例はきわめて少なく， 安定性を含め, 検討を要するあのである.

\section{3. トリコテセン類 (TR) とゼアラレノン (Z)}

Fusarium のマイコトキシンには主として TR 類と Z があるが，乙れらに関して，すぐれた総 説 ${ }^{15)}$ が出されているので，乙とではFusarium 菌種と TR および Z の産生性についてふれること としたい. Booth の分類体系により，TR 系トキシンと Z について，代表的な報告例での検討結 果をとりまとめたのが Table 4 である.

この表では Burmeister ら ${ }^{16)}$ は T-2 トキシン (T-2) 産生菌を対象とし, Ueno は17)フザレノン-X $(\mathrm{F}-\mathrm{X})$, ニバレノール， ネオソラニオール(NS), T-2, ジアセトオキシスシルペノール，ジアセチ ルニバレノールなどを対象としている.

著者ら ${ }^{18)}$ は国産落花生より多数分離された Fusarium につき，T-2, NS, F-X 産生菌を検索した. TR 系トキシンについてみると，Liseola section の $F$. moniliforme を除いた，ほとんどすべての section にわたって産生菌が認められている. これに対し, Z は Sporotrichiella, Arthrosporiella, Gibbosum, Discolor の各 Section に限定されているのは興味深い点である*.

* F. avenaceum, $F$. semitectum, $F$. equiseti, $F$. graminearum, $F$. culmorum などは Snyder-Hansen の分類体系で は, いずれも F. roseum の品種 (cultivar) とみなされているものである. 
Table 4. Trichothecenes and zearalenone production by Fusarium species

\begin{tabular}{|c|c|c|c|c|c|c|c|}
\hline \multirow{2}{*}{ Section } & \multirow{2}{*}{ Species } & \multicolumn{3}{|c|}{ Trichothecenes } & \multicolumn{3}{|c|}{ Zearalenone } \\
\hline & & A & $\mathrm{B}$ & $\mathrm{C}$ & $\mathrm{D}$ & $\mathrm{E}$ & F \\
\hline \multirow[t]{2}{*}{ Sporotrichiella } & F. tricinctum & $10 / 14$ & $4 / 6$ & & $0 / 12$ & $3 / 19$ & $1 / 4$ \\
\hline & $F \cdot$ poae & & $1 / 1$ & & & & \\
\hline \multirow[t]{3}{*}{ Arthrosporiella } & F. sporotrichioides & & $3 / 3$ & & & & $0 / 7$ \\
\hline & $F$. avenaceum & & $1 / 3$ & & & $0 / 1$ & $1 / 2$ \\
\hline & F. semitectum & $2 / 8$ & & $11 / 29$ & & & \\
\hline \multirow[t]{4}{*}{ Gibbosum } & $F$. equiseti & $6 / 8$ & $1 / 1$ & $6 / 18$ & & $3 / 6$ & $0 / 1$ \\
\hline & $F$. acuminatum & & & & & $0 / 4$ & \\
\hline & $F$. concolor & & & $2 / 2$ & & & \\
\hline & (F. gibbosum) & & $0 / 3$ & & & $1 / 1$ & $2 / 5$ \\
\hline \multirow[t]{5}{*}{ Discolor } & $F$. graminearum & & $1 / 4$ & & & $21 / 23$ & \\
\hline & F. culmorum & & $2 / 6$ & & & $3 / 3$ & $3 / 4$ \\
\hline & $F$. sambucinum & & & & & $0 / 1$ & \\
\hline & $F$. sulphureum & & & $1 / 2$ & & & \\
\hline & $(F \cdot$ roseum $)$ & & $4 / 8$ & & $43 / 43$ & $3 / 12$ & $9 / 28$ \\
\hline Lateritium & $F$. lateritium & $1 / 7$ & $0 / 1$ & $1 / 2$ & $0 / 1$ & & $1 / 1$ \\
\hline Liseola & $F$. moniliforme & & $0 / 8$ & $0 / 7$ & $0 / 5$ & $0 / 11$ & $0 / 3$ \\
\hline Arachnites & $F$. nivale & & $3 / 6$ & & $0 / 2$ & $0 / 7$ & $0 / 2$ \\
\hline Elegans & F. oxysporum & & $2 / 13$ & $11 / 30$ & $0 / 2$ & $0 / 15$ & $0 / 12$ \\
\hline Martiella & $F$. solani & & $2 / 6$ & $2 / 12$ & $0 / 1$ & $0 / 9$ & $0 / 4$ \\
\hline Episphaeria & (F.episphaeria) & & $2 / 3$ & & $0 / 1$ & $0 / 1$ & $0 / 2$ \\
\hline Spicarioides & (F. rigidiusculum) & & $1 / 4$ & & $0 / 1$ & & $0 / 4$ \\
\hline
\end{tabular}

*1 A: Data from Burmeister et al. (16), B: Data from Ueno et al. (17), C: Data from Ichinoe et al. (18), D: Data from Eugenio et al. (19), E: Data from Caldwell et al. (20), F: Data from Ishii et al. (21)

F. moniliforme に Z の産生能ありとする報告むみられるが検討を要する.

TR の自然污染例は，わが国の赤カビ罹病麦よりニバレノール，デオキシニバレノールを検出し た報告22)の他，二・三が知られるが少ない.

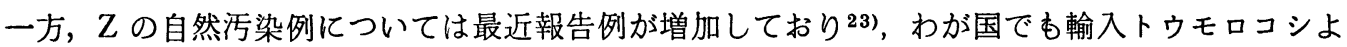
り Z を見出しているので24)，さらに検討がのぞまれる.

\section{引用 文 献}

1）宮木高明ら：食衛誌， 11，373 (1970).

2) 一言広ら：食衛誌, 14, 364 (1973).

3）森実ら：食衛誌，15，94 (1974).

4）小笠原和夫ら：北海道衛研報, 25, 67 (1975).

5）鶴田理ら：日菌報, 15, 258 (1974).

6) Schroeder, H. W., Kelton, W. H.: Appl. Microbiol., 30, 589 (1975).

7) Natori, S., et al.: Chem. Pharm. Bull., 18, 2259 (1970).

8) Yamazaki, M., et al.: Appl. Microbiol., 20, 452 (1970).

9）一戸正勝ら：食衛誌，16，381 (1975).

10) Ciegler, A.: Can. J. Microbiol., 18, 631 (1972).

11) Scott, P. M., et al.: J. Agr. Food Chem., 20, 1103 (1972). 
12) Mintzlaff, H.-J., et al.: Z. Lebensm.-Unters.-Forsch., 150, 133 (1972).

13）杉本貞三ら：第 3 回マイコトキシン研究会要旨 (1976).

14）一户正勝ら：日本菌学会第19回大会要旨 (1975).

15）上野芳夫：食衛誌，14，403， 501 (1973).

16) Burmeister, H. R., et al.: Appl. Microbiol., 21, 673 (1971).

17) Ueno, Y., et al.: Appl. Microbiol., 25, 699 (1973).

18）一戸正勝ら：食衛誌，14, 666 (1973) (Abstract).

19) Eugenio, C. P., et al.: Phytopathology, 60, 1055 (1970).

20) Caldwell, R. W., et al.: Appl. Microbiol., 20, 31 (1970).

21) Ishii, K., et al.: Appl. Microbiol., 27, 625 (1974).

22）諸岡信一ら：食衛誌，13，368（1972).

23) Hesseltine, C. W.: Mycopath. Mycol. appl., 53, 141 (1974).

24）杉本貞三ら：食衛誌，17，12（1975). 